\title{
Changes in soil moisture and riparian forest structure after a dam construction
}

\author{
Vagner Santiago do Vale', Jamir Afonso do Prado Júnior ${ }^{2}$, Sérgio de Faria Lopes ${ }^{3}$, \\ Carolina de Silvério Arantes ${ }^{2}$, Diego Raymundo Nascimento ${ }^{2,4}$, Olavo Custódio Dias-Neto5, \\ André Eduardo Gusson ${ }^{6}$, Lilian Cristina da Silva Santos' ${ }^{1}$ Ivan Schiaviniं ${ }^{2}$
}

\author{
'Universidade Estadual de Goiás, Campus Ipameri, Rodovia GO-330 Km 241, CEP 75780-000, Ipameri, Goiás, Brasil. \\ vagner.vale@veg.br; liliancristina_2011@hotmail.com \\ 2 Universidade Federal de Uberlândia, Campus Umuarana, Avenida Amazonas s/n, CEP 38400-902, Uberlândia, Minas Gerais, Brasil. \\ jamirjunior@yahoo.com.br; ivanschiavini@gmail.com; carolina.s.arantes@gmail.com. \\ ${ }^{3}$ Universidade Estadual da Paraíba, Rua Baraúnas, 351, CEP 58429-500, \\ Campina Grande, Paraíba, Brasil. defarialopes@gmail.com \\ ${ }^{4}$ Universidade Federal de Juiz de Fora, Campus Universitário, Rua José Lourenço Kelmer, S/n, CEP 36036-330, Juiz de Fora, \\ Minas Gerias, Brasil. diegoraynascimento@gmail.com. \\ ${ }^{5}$ Fundação Carmelitana Mário Palmério, Avenida Brasil Oeste, s/n, CEP 38500-000, Monte Carmelo, Minas Gerias, Brazil. \\ olavonneto@gmail.com \\ ${ }^{6}$ Instituição Luterana de Ensino Superior, Avenida Beira Rio, 283, CEP 75503-480, Itumbiara, Goiás, Brazil. desrp4@yahoo.com.br
}

Received on 29.VIII.2016

Accepted on 16.X.2018

DOI 10.21826/2446-8231201873304

\begin{abstract}
This study evaluated the impacts of water flow reduction in soil moisture and changes in the arboreal community in a riparian forest in Minas Gerais. Our hypothesis is that few years after river flow reduction can alter soil moisture and change tree community structure. We performed soil moisture analyses to confirm reduction in soil moisture and a four-year-monitoring of the tree community structure in 1.1 ha of riparian forest. Soil moisture was reduced, especially during the dry season at the sector located near the original river flow. In this sector we found higher mortality and broken stems of living trees, strongly reducing basal area and causing a little reduction in trees density. This study highlights the strong impacts of dams' construction in the flora and water availability downstream from the dam.
\end{abstract}

Keywords: dynamics, floristic changes, impoundment, mortality

RESUMO - Mudanças na umidade do solo e na estrutura da floresta ripária após a construção de barragem. Este estudo avaliou os impactos da redução do fluxo das águas do rio na umidade do solo e mudanças na comunidade arbórea pós-represamento em uma floresta ciliar em Minas Gerais. Nossa hipótese é que poucos anos após a redução do fluxo do rio pode alterar a umidade do solo e, por consequência, mudar a estrutura da comunidade arbórea. Realizamos análises de umidade do solo para confirmar a redução na umidade do solo e um monitoramento de quatro anos da estrutura da comunidade arbórea em 1,1 ha de mata ciliar. A umidade do solo foi reduzida, especialmente durante a estação seca no setor localizado próximo ao fluxo original do rio. Neste setor encontramos maior mortalidade e fustes quebrados de árvores vivas, reduzindo fortemente a área basal e causando uma pequena redução na densidade de árvores. Este estudo destaca os fortes impactos da construção de barragens na flora e disponibilidade de água a jusante da barragem.

Palavras-chave: dinâmica, modificações florísticas, represamento, mortalidade

\section{INTRODUCTION}

The majority of the largest rivers on earth $(60 \%)$ are moderately/strongly fragmented by dams (Ravenga et al. 2000). Most of the dams are used for hydropower production, triggering environmental problems, such as greenhouse emission (Fearnside 2002, Truffer et al. 2003), sediment retention (Nilsson \& Berggren 2000), interruption of fish migration (Friedl \& Wuest 2002), and extinction of many amphibians, birds and fishes direct associated with the watercourse (Ravenga et al. 2000).
The effects of dams on the remaining tree flora are hard to evaluate because trees are long-lived organisms and long-term studies are necessary to evaluate local changes. Modifications on plant community may be dramatic because they represent the basal component of most ecosystems (Loreau et al. 2001) and, therefore, changes in vegetation component may lead to changes in many other taxa.

Some studies have reported direct effects of dams on tree community such as change in species composition, structure and/or richness (Nilsson \& Grelsson 1995, Nilsson et al. 1997, Vale et al. 2013, Vale et al. 2015a). Most of the 
studies comprised effects of water increase upstream dams, neglecting problems associated with water flow reduction downstream, especially immediately after flow reduction. When dams are constructed, it is often necessary to change the river course, reducing water flow downstream the dams (Nilsson \& Berggren 2000) and depleting the water table (Ward 1998).

In riparian communities, where water availability is high, (Smith et al. 1991) these impacts should be even stronger, increasing drought stress, decreasing vegetation cover by death of many trees or stems (Vale et al. 2015b); or, in extreme cases, destroying the whole riparian ecosystem (Smith et al. 1991).

Riparian species are directly affected by the water course, because they are sensitive to reductions in water flow and groundwater level (Schume et al. 2004, Vale et al. 2014), but species may respond in different ways according to their life strategies. In seasonal dry environments, it is commonly observed a mix of tree species that are strongly dependent of the water from the river coexisting and competing for the same resources with species that are able to resist to long droughts (Vale et al. 2015b). Thus, high species richness is expected in riparian dry environments mainly due to its high heterogeneity caused by the occasional floods, variations in topography, groundwater level and upland floristic influence (Naiman et al. 1993, Nilsson \& Svedmark 2002, Rocha et al. 2005). Therefore, changes in plant species richness are expected due to water flow reduction (Vale et al. 2015b).

This scenario of water flow reduction is certainly disadvantageous to some species that depend on rivers' water but may favor other species more drought resistant. However, this effect should be more severe near the riverside and less intense far from the river. Thus, considering the lack of studies that evaluate the effects of water flow reduction caused by dams to tree communities, this work aims at quantifying the effects of drought caused by a dam in a riparian forest. The dam reduced the river discharge and a riparian forest that was near the riverbed is now at 10 to 50 meters away from the waterline. Thus, we hypothesized that, after the reservoir construction, 1) the soil moisture in sectors closer to the riverside (before water flow reduction) should experience a higher decrease than in inland sectors; 2) the higher negative impact in the forest community should occur at the riverside sector, with high mortality and diversity and basal area reduction as a response to the soil moisture decrease, 3 ) sectors previously nearest the riverside should have the larger negative dynamics rates (mortality and decrement).

\section{MATERIAL AND METHODS}

\section{Study area}

This study was conducted in a riparian forest (18 $\left.8^{\circ} 47^{\prime} 52^{\prime \prime} \mathrm{S}, 48^{\circ} 08^{\prime} 54^{\prime \prime} \mathrm{W}\right)$ in Minas Gerais, Southeastern Brazil. The region experiences a tropical savanna climate (Aw Mega thermic climate of Köppen), characterized by rainy summers (October to March) and dry winters (April to September). Mean annual rainfall is $1595 \mathrm{~mm}$, the dry season lasts for from four to six months (with less than $100 \mathrm{~mm}$ rainfall during the dry season) and mean annual temperature is $22^{\circ} \mathrm{C}$ (Alvares et al. 2013).

The area is located at the Araguari valley, within a hilly terrain with sedimentary and basaltic layers to gneiss and schist in the valley bottom (Rodrigues \& Silva 2012). The riparian forest occurs along the main drainage of Araguari River, and had a gradual transition from semideciduous forest on the lower slopes to savanna in the uplands (Rodrigues \& Silva 2012). The riparian forest is located in the influence area of Amador Aguiar dam that was built in December, 2005. Before the dam construction, the forest was close to the river margin. After the dam

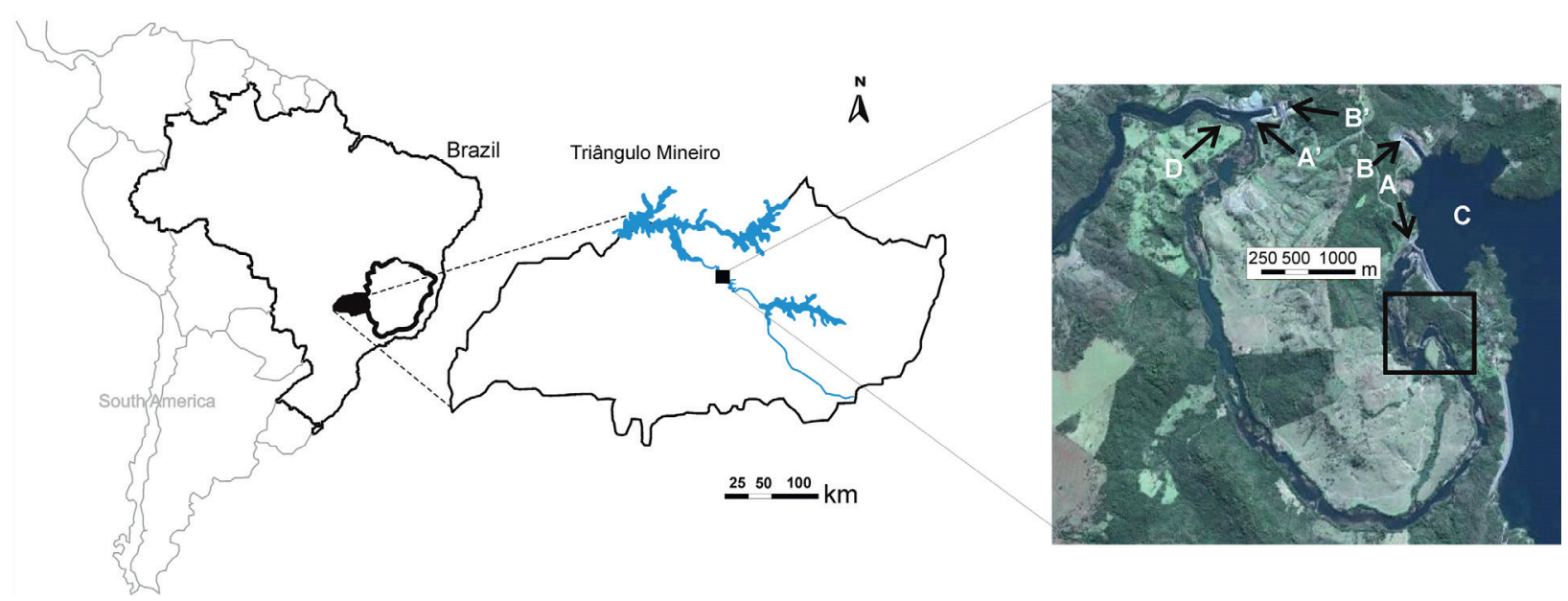

Fig. 1. Satellite image of a riparian forest on southern Brazil. Study area image with square showing plots locations. A= Spillway and the beginning of Reduced Outflow Stretch, A' = end of Reduced Outflow Stretch, B = hydroeletric dam, B' = end of hydroelectric dam, C= artificial lake created by dam, $\mathrm{D}=$ river patch returns to normal flow. The square ilustrates the study area. 
construction, the water flow was strongly reduced (from 359 to $7 \mathrm{~m} 3 \mathrm{~s}-1$, Consórcio Capim Branco e Energia CCBE 2005), and the forest became at 10-50 $\mathrm{m}$ far from the water course (Fig. 1).

\section{Soil moisture}

To verify if soil moisture was affected by the watercourse reduction we carried out soil samples before and after the dam construction. We carried out five soil samples in the riparian forest at three distinct depths, namely, 0-10, 20-30 and 40-50 cm (total of 30 samples) along the riparian forest near the original river $(5 \mathrm{~m}$ of distance from the river, namely "riverside" sectors). We repeated this sampling protocol every three months to cover the middle of rainy (December), end of rainy (May) and middle of dry (June) and end of dry (September) seasons. Same procedure was done $15 \mathrm{~m}$ of distance from the original riverside (namely "inland" sectors). This allowed us to verify how soil moisture was affected in different depths and seasonality. Soil collections and determination of its moisture was carried out before the spillway construction in 2005 (T0), after completion of construction works in 2006 (T1) and during the third year of water flow reduction in 2008 (T3). Soil moisture was calculated using the formula: (humid weight - dry weight).dry weight ${ }^{-1} .100$, based on Empresa Brasileira de Pesquisa Agropecuária (2006).

To check soil data normality we performed Lilliefors test (Lilliefors 1967), but the soil data did not fit a normal distribution. Therefore, to determine damming effects at the different distances, we carried out separate Friedman tests (Friedman 1939) and Post-hoc Wilcoxon test for $5 \mathrm{~m}$ and $15 \mathrm{~m}$ from the shore. These tests were made at each soil depth in each season (middle of rainy, end of rainy, middle of dry, and end of dry season), comparing the three years of measurement (T0, T1, and T3).

To compare damming effects on soil moisture between $5 \mathrm{~m}$ and $15 \mathrm{~m}$ we performed Wilcoxon tests between each year (T0, T1 and T3). Thus, we compared all soil moisture near and far from shore before damming (T0), one year after damming (T1), and three years after damming (T3) with a pairwise test. The intention was to show that near the shore, the moisture increases after damming more than at $15 \mathrm{~m}$ distant from the shore. All soil analysis were made in Statistica Software (StatSoft 2005) and Excel Software.

\section{Species sampling and dynamic rates}

Before the dam construction $\left(\mathrm{T}_{0}, 2005\right), 96$ permanent sample plots $\left(100 \mathrm{~m}^{2}\right)$ were established, with 63 plots which were located just beside the watercourse $(0-10 \mathrm{~m}$, from now called "riverside" sector), and 33 plots between 10-20m distance from the watercourse (called "inland sectors"). In the first census $\left(\mathrm{T}_{0}\right)$, all trees with stem diameter at breast height $(\mathrm{DBH}, 1.30 \mathrm{~m}) \geq 5 \mathrm{~cm}$ were tagged, their diameter were measured, the height was estimated, and trees were identified to species level. In the second census, after four years $\left(\mathrm{T}_{4}\right)$, all trees were re-measured and dynamic rates were evaluated.

The evaluated dynamics rates were mortality, recruitment, outgrowth and ingrowth, which were calculated in terms of annual exponential rates (Sheil et al. 1995, Sheil et al. 2000). Outgrowth rate refers to the sum of basal area of dead trees and the basal area of dead branches of living trees. In growth rate refers to the sum basal area growth of surviving trees and the basal area of recruits.

To check data normality we performed Lilliefors test to the number of recruit, number of dead trees, number of trees and basal area before and after damming but the data did not follow a normal distribution. Then, we performed Mann-Whitney tests comparing riverside and inland plots to number of individuals at $\mathrm{T}_{0}$ and $\mathrm{T}_{4}$, to the number and basal area of dead individuals, to basal area of dead trunks in $\mathrm{T}_{0}-\mathrm{T}_{4}$ period of still alive trees (those with more than one trunk in $\mathrm{T}_{0}$ ), to the number and basal area of recruits, to the growth in $T_{0}-T_{4}$ period and to the basal area in $T_{0}$ and $T_{4}$.

We did a Wilcoxon test in each sector (riverside and inland) comparing the individuals and basal area found in the plots in $\mathrm{T}_{0}$ and $\mathrm{T}_{4}$. The Shannon diversity index was calculated and to both sectors and we did the Hutcheson $\mathrm{t}$ tests to compare this index in each sector in $\mathrm{T}_{0}$ and $\mathrm{T}_{4}$, and to compare riverside to inland $\mathrm{T}_{0}$ and then in $\mathrm{T}_{4}$ period. Then, to evaluate floristic differences caused by dams we compare riparian forest sectors by Morisita-Horn index using density of species in $\mathrm{T}_{0}$ and $\mathrm{T}_{4}$ and Jaccard Index using presence-absence of species. Using the recruits and the dead trees in both sectors, we compared the similarity of recruits and the similarity of dead trees by Morisita-Horn index. All these analysis were made in FITOPAC Software (Shepherd 2004) and Statistica program (StatSoft 2005).

To evaluate changes in forest dynamic we calculated turnover rates per individual plant unit and basal area through mortality-recruitment rates and outgrowth-ingrowth rates (Oliveira-Filho et al. 2007). Then we evaluated the net change (Korning \& Balslev 1994) to individuals (ChN) and basal area (ChBA) and developed an overall net change based in average of $\mathrm{ChN}$ and $\mathrm{ChBA}$ rates.

\section{RESULTS}

\section{Soil moisture}

In the riverside sector, a significant reduction of soil moisture was observed in the middle and in the end of dry season at $0-10 \mathrm{~cm}$ and $20-30 \mathrm{~cm}$ depths after flow reduction (Table 1). Soil moisture in the riverside sector did not change at $40-50 \mathrm{~cm}$ soil depth during the dry season and in any depths during the rainy season. In the inland sector, no significant differences in soil moisture were found 
Table 1. Friedman test before, one year and three years after dam construction to $0-10 \mathrm{~cm}, 20-30 \mathrm{~cm}$ and $40-50 \mathrm{~cm}$ deep near and far the shore in a riparian forest in southern Brazil. In bold, $\mathrm{p}<0.05 . \mathrm{M}=$ median, $\mathrm{Q}=$ quartil interval $\mathrm{p}=$ significance value, $\mathrm{F}=$ friedman test value, $\mathrm{W}=$ wilcoxon paried test. The letter sequence means the years T0, T1, T3; different letters means distinct statistical results $(\mathrm{p}<0.05)$, where a $>\mathrm{b}>\mathrm{c}$.

\begin{tabular}{|c|c|c|c|c|c|c|c|c|c|c|c|c|c|}
\hline & \multirow{2}{*}{ T0 } & \multirow{2}{*}{$\mathrm{T} 1$} & \multirow{2}{*}{$\mathrm{T} 3$} & \multicolumn{3}{|c|}{$5 m$ - Near } & & \multirow{2}{*}{ T0 } & \multirow{2}{*}{$\mathrm{T} 1$} & \multirow{2}{*}{$\mathrm{T} 3$} & \multicolumn{2}{|c|}{$15 m-$ Far } & \multirow{2}{*}{ W } \\
\hline & & & & $\mathrm{p}$ & $\mathrm{F}$ & W & & & & & $\mathrm{p}$ & $\mathrm{F}$ & \\
\hline & & & & & & & $0-10 \mathrm{~cm}$ & & & & & & \\
\hline Middle Rainy & 32.08 & 30.43 & 28.77 & 0.819 & 0.4 & aaa & & 29.55 & 32.73 & 24.68 & 0.165 & 3.6 & aaa \\
\hline End Rainy & 24.00 & 30.95 & 37.25 & 0.091 & 4.8 & aaa & & 30.77 & 21.95 & 28.85 & 0.247 & 2.8 & aaa \\
\hline Middle Dry & 22.41 & 10.64 & 7.04 & 0.022 & 7.6 & $a b b$ & & 22.92 & 12.73 & 13.04 & 0.074 & 5.2 & aaa \\
\hline \multirow[t]{2}{*}{ End Dry } & 14.29 & 8.93 & 12.00 & 0.015 & 8.4 & $a b b$ & & 11.86 & 9.68 & 14.06 & 0.165 & 3.6 & aaa \\
\hline & & & & & & & $20-30 \mathrm{~cm}$ & & & & & & \\
\hline Middle Rainy & 32.00 & 32.08 & 24.59 & 0.400 & 0.8 & aaa & & 22.64 & 27.12 & 25.76 & 0.400 & 0.8 & aaa \\
\hline End Rainy & 21.52 & 17.50 & 30.19 & 0.247 & 2.8 & aaa & & 27.85 & 14.29 & 23.33 & 0.247 & 8.4 & aaa \\
\hline Middle Dry & 12.00 & 10.00 & 5.75 & 0.015 & 2.8 & $\mathrm{aab}$ & & 12.07 & 11.48 & 9.86 & 0.692 & 0.7 & aaa \\
\hline \multirow[t]{2}{*}{ End Dry } & 13.21 & 9.26 & 10.77 & 0.015 & 8.4 & $\mathrm{abb}$ & & 10.17 & 10.77 & 11.67 & 0.692 & 0.7 & aaa \\
\hline & & & & & & & $40-50 \mathrm{~cm}$ & & & & & & \\
\hline Middle Rainy & 28.00 & 32.76 & 29.23 & 0.819 & 0.4 & aaa & & 21.43 & 21.74 & 21.62 & 0.819 & 0.4 & aaa \\
\hline End Rainy & 16.67 & 16.28 & 28.07 & 0.247 & 2.8 & aaa & & 16.92 & 13.21 & 21.88 & 0.165 & 3.6 & aaa \\
\hline Middle Dry & 12.07 & 17.02 & 9.09 & 0.819 & 0.4 & aaa & & 12.70 & 10.17 & 12.16 & 0.247 & 2.8 & aaa \\
\hline End Dry & 17.02 & 11.54 & 10.61 & 0.247 & 2.8 & aaa & & 10.45 & 10.45 & 14.04 & 0.165 & 3.6 & aaa \\
\hline
\end{tabular}

Table 2. Wilcoxon test in three depths between near and distant to the shore for four season in a riparian forest in southern Brazil. MedR = Median for riverside, MedI = Median for inland, $\mathrm{MR}=$ middle of rainy season, $\mathrm{ER}=$ end of rainy season, $\mathrm{MD}=$ middle of dry season, $\mathrm{ED}=$ end of dry season. In bold $\mathrm{p}<0.05$.

\begin{tabular}{|c|c|c|c|c|c|}
\hline \multicolumn{2}{|c|}{ Measurement Times } & \multirow{2}{*}{$\frac{\text { MedR }}{31.91}$} & \multirow{2}{*}{$\frac{\text { MedI }}{22.64}$} & \multirow{2}{*}{$\begin{array}{c}\mathrm{p} \\
\mathbf{0 . 0 0 2}\end{array}$} & \multirow{2}{*}{$\frac{\mathrm{Z}}{3.124}$} \\
\hline & T0 & & & & \\
\hline \multirow[t]{3}{*}{ MR } & $\mathrm{T} 1$ & 28.68 & 25.65 & 0.211 & 1.215 \\
\hline & $\mathrm{T} 3$ & 28.76 & 23.61 & 0.233 & 1.193 \\
\hline & $\mathrm{T} 0$ & 27.63 & 21.51 & 0.069 & 1.817 \\
\hline \multirow[t]{3}{*}{ ER } & $\mathrm{T} 1$ & 20.51 & 17.02 & 0.069 & 1.817 \\
\hline & $\mathrm{T} 3$ & 30.18 & 24.24 & 0.078 & 1.761 \\
\hline & $\mathrm{T} 0$ & 13.72 & 13.79 & 0.954 & 0.056 \\
\hline \multirow[t]{3}{*}{ MD } & $\mathrm{T} 1$ & 11.76 & 11.11 & 0.909 & 0.114 \\
\hline & $\mathrm{T} 3$ & 7.59 & 12.16 & 0.017 & 2.285 \\
\hline & $\mathrm{T} 0$ & 14.27 & 10.53 & 0.001 & 3.408 \\
\hline \multirow[t]{2}{*}{ ED } & $\mathrm{T} 1$ & 9.43 & 10.44 & 0.125 & 1.533 \\
\hline & $\mathrm{T} 3$ & 10.76 & 12.50 & 0.306 & 1.022 \\
\hline
\end{tabular}

for any depth and season (Table 1). We made a conceptual figure to summarize the main events occurred due to four years of water flow reduction on soil moisture (Fig. 2).

Comparing riverside and inland soil before dams construction, the Wilcoxon test showed the dam construction impacts on soil moisture (Table 2). Before this building, in the middle of rainy season and end the of dry season, soil had more moisture in riverside than in inland sector (Table 2). However after flow reduction riverside soil became as drier as inland soil (Table 2). The waterflow reduction reduced the soil moisture only in $\mathrm{T} 3$, becoming drier in the riverside than in the inland sector. 
T0 Before the reduction of the water flow

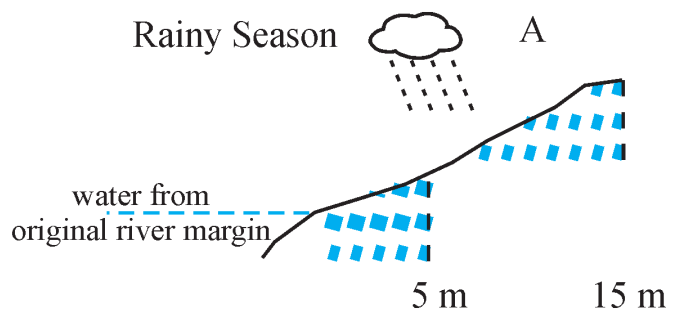

C

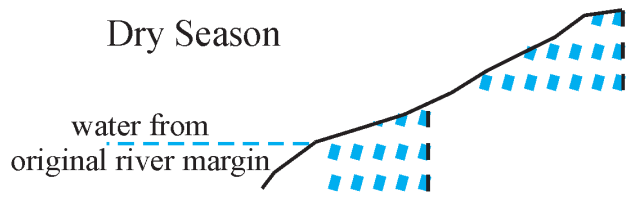

T4 Four years with water flow reduction

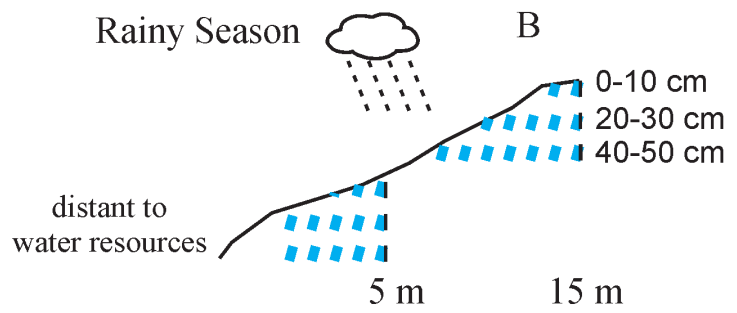

D

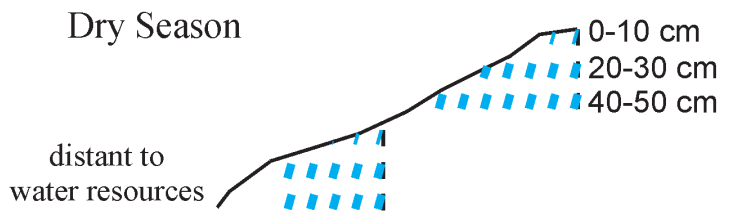

Fig. 2. Soil moisture changes that occurred due to construction of the dams. A and C represent soil moisture in dry forests before damming, and B and D represent soil moisture after damming construction. The continuous line represents soil surface; vertical black bars represent soil sampling sites; blue bars represent soil moisture and their thickness illustrates soil moisture; and thicker bars represent more moisture. After dam influence, soil moisture increased mainly in the dry season and mainly near the lakeshore.

\section{Floristic and structural changes}

The riverside and inland sectors demonstrated structural changes in four years (Table 3) with many species changes too (Table 4). The riverside was more affected than inland sectors in these four years with low water flow. The mortality in the riverside was $21.97 \%$ of trees and $17.18 \%$ of basal area. The number of trees was reduced in $11.52 \%$ and the basal area in $8.73 \%$ near the riverside (Table 3). The mortality in the inland sector was $15.29 \%$ of trees and $17.30 \%$ in basal area, however with smaller depletion of basal area compared to riverside (Table 3).

The Mann-Whitney test showed higher basal area lost by mortality or dead trunks in the riverside (Decrement), and same for growth and the basal area at T0 period (see statistical results in Table 3). However the basal area lost (Decrement) surpasses the basal area gain (Growth), thus the basal area in T0 was higher in the riverside than the inland, but in T4 the basal area in the riverside become similar to the inland basal area, with no statistical difference (Table 3).

When T0-T4 changes were compared in each riparian sector, the Wilcoxon tests showed reduction in the number of trees at the riverside in $\mathrm{T} 0$ period $(\mathrm{gl}=63 ; \mathrm{z}=-3.120$; $\mathrm{p}$ $=0.002$ ) and higher basal area in the inland sector in T4 period $(\mathrm{gl}=32, \mathrm{z}=2.225, \mathrm{p}=0.026)$. There were no statistical significance to number of individuals in the inland sector and to basal area in the riverside $(\mathrm{gl}=32, \mathrm{z}=-0.727$, $\mathrm{p}=0.467 ; \mathrm{gl}=62, \mathrm{z}=0.445, \mathrm{p}>0.65)$. Otherwise, on the inland sector there was little but constant increase in basal area per plot. We made a conceptual figure to summarize the main events occurred due to four years of water flow reduction (Fig. 3).

Shannon diversity index was similar among years within riverside and inland sector (Hutcheson " $t$ " test

Table 3. General changes by hectare riverside and distant sectors four years after river reduction flow in a riparian forest in southern Brazil. Wilcoxon $\mathrm{U}$ test results comparing the parameters near and distant to the shore. In bold $\mathrm{p}<0.05 . \mathrm{N}=$ number of individuals, $\mathrm{BA}=$ basal area.

\begin{tabular}{|c|c|c|c|c|c|}
\hline General data (hectare) & Riverside $\left(\right.$ ha $\left.^{-1}\right)$ & Distant $\left(\mathrm{ha}^{-1}\right)$ & $\mathrm{U}$ & $Z$ & $\mathrm{p}$ \\
\hline $\mathrm{N}^{\circ}$ ind $\mathrm{T} 0$ & 1336.51 & 1190.91 & 861.0 & 1.16 & 0.25 \\
\hline $\mathrm{N}^{\circ}$ ind $\mathrm{T} 4$ & 1182.54 & 1145.45 & 989.5 & -0.15 & 0.88 \\
\hline Mortality (N) & 293.65 & 206.06 & 841.0 & 1.32 & 0.19 \\
\hline Mortality (BA) & 7.83 & 1.87 & 674.0 & 2.63 & 0.01 \\
\hline Decrement (BA) & 2.29 & 0.94 & 434 & 2.93 & 0.01 \\
\hline Recruits (N) & 139.68 & 160.61 & 948.5 & -0.47 & 0.64 \\
\hline Recruits (BA) & 0.36 & 0.42 & 916.5 & -0.72 & 0.47 \\
\hline Growth (BA) & 5.57 & 3.18 & 756 & 2.08 & 0.03 \\
\hline Basal area $\mathrm{T} 0\left(\mathrm{~m}^{2}\right)$ & 45.63 & 34.00 & 679.0 & 2.59 & 0.01 \\
\hline Basal area $\mathrm{T} 4\left(\mathrm{~m}^{2}\right)$ & 41.59 & 34.70 & 861.0 & 1.16 & 0.25 \\
\hline
\end{tabular}


Table 4. Floristic list and number of trees per species found in a riparian forest in southern Brazil, in decrescent order of number of trees. $\mathrm{R}=$ Riverside, I = Inland, Wd = water-dependence species, T0 = First period of measurement (before damming), T4 = four years of measurement (four years after damming)

\begin{tabular}{|c|c|c|c|c|c|}
\hline Species & RT0 & I T0 & R T4 & I T4 & $\mathrm{Wd}$ \\
\hline Hirtella gracilipes (Hook. f.) Prance & 164 & 10 & 141 & 10 & $\mathrm{X}$ \\
\hline Alibertia edulis (Rich.) A. Rich. ex DC. & 69 & 5 & 58 & 4 & $\mathrm{X}$ \\
\hline Protium heptaphyllum (Aubl.) Marchand & 56 & 37 & 55 & 39 & $\mathrm{X}$ \\
\hline Inga laurina (Sw.) Willd. & 48 & 15 & 36 & 16 & $\mathrm{X}$ \\
\hline Tapirira guianensis Aubl. & 46 & 14 & 43 & 9 & $\mathrm{X}$ \\
\hline Copaifera langsdorffii Desf. & 38 & 9 & 34 & 10 & - \\
\hline Coussarea hydrangeifolia (Benth.) Müll. Arg. & 35 & 15 & 29 & 12 & $\mathrm{X}$ \\
\hline Inga edulis Mart. & 34 & 2 & 20 & 2 & $\mathrm{X}$ \\
\hline Siparuna guianensis Aubl. & 31 & 47 & 36 & 62 & - \\
\hline Coccoloba mollis Casar. & 29 & 25 & 22 & 17 & - \\
\hline Hymenaea courbaril L. & 23 & 8 & 21 & 9 & - \\
\hline Casearia sylvestris Sw. & 19 & 1 & 16 & 1 & - \\
\hline Matayba guianensis Aubl. & 17 & 14 & 15 & 13 & - \\
\hline Ormosia arborea (Vell.) Harms & 15 & 2 & 14 & 2 & - \\
\hline Platypodium elegans Vogel & 14 & 6 & 12 & 7 & - \\
\hline Terminalia glabrescens Mart. & 14 & 7 & 11 & 7 & - \\
\hline Xylopia aromatica (Lam.) Mart. & 12 & 6 & 13 & 2 & - \\
\hline Cheiloclinium cognatum (Miers) A.C. Sm. & 12 & 2 & 13 & 2 & - \\
\hline Cordiera sessilis (Vell.) Kuntze & 11 & 5 & 11 & 7 & $\mathrm{X}$ \\
\hline Bauhinia ungulata L. & 10 & 11 & 6 & 8 & - \\
\hline Myrtaceae 1 & 10 & 0 & 5 & 0 & - \\
\hline Ficus sp1 & 9 & 3 & 10 & 3 & - \\
\hline Andira sp. & 8 & 8 & 9 & 7 & - \\
\hline Salacia elliptica (Mart. ex Schult.) G. Don & 8 & 2 & 8 & 2 & - \\
\hline Unonopsis guatterioides (A. DC.) R.E. Fr. & 8 & 0 & 7 & 0 & - \\
\hline Myrcia splendens (Sw.) DC. & 7 & 24 & 6 & 19 & - \\
\hline Eugenia florida DC. & 7 & 0 & 5 & 1 & $\mathrm{X}$ \\
\hline Cecropia pachystachya Trécul & 7 & 0 & 7 & 0 & $\mathrm{X}$ \\
\hline Erythroxylum daphnites Mart. & 6 & 4 & 5 & 5 & - \\
\hline Apuleia leiocarpa (Vogel) J.F. Macbr. & 5 & 12 & 7 & 12 & - \\
\hline Zanthoxylum riedelianum Engl. & 5 & 5 & 3 & 4 & - \\
\hline Micropholis venulosa (Mart. \& Eichler) Pierre & 5 & 2 & 8 & 2 & - \\
\hline Chomelia ribesioides Benth. ex A. Gray & 5 & 1 & 4 & 1 & - \\
\hline Byrsonima laxiflora Griseb. & 4 & 12 & 8 & 14 & - \\
\hline Pouteria torta (Mart.) Radlk. & 4 & 8 & 4 & 9 & $\mathrm{X}$ \\
\hline Tocoyena formosa (Cham. \& Schltdl.) K. Schum. & 4 & 0 & 3 & 0 & - \\
\hline Miconia albicans (Sw.) Steud. & 3 & 4 & 2 & 4 & - \\
\hline Dipteryx alata Vogel & 3 & 1 & 2 & 2 & - \\
\hline Guazuma ulmifolia Lam. & 3 & 1 & 3 & 1 & - \\
\hline Ouratea castaneifolia (DC.) Engl. & 3 & 1 & 3 & 1 & - \\
\hline Cupania vernalis Cambess. & 3 & 0 & 3 & 1 & - \\
\hline Trichilia catigua A. Juss. & 3 & 1 & 2 & 1 & - \\
\hline Acacia glomerosa Benth. & 2 & 6 & 1 & 5 & - \\
\hline
\end{tabular}


Table 4. Cont.

\begin{tabular}{|c|c|c|c|c|c|}
\hline Species & RT0 & I T0 & R T4 & I T4 & $\mathrm{Wd}$ \\
\hline Astronium graveolens Jacq. & 2 & 2 & 3 & 3 & - \\
\hline Myrcia tomentosa (Aubl.) DC. & 2 & 2 & 2 & 2 & - \\
\hline Siphoneugena densiflora $\mathrm{O}$. Berg & 2 & 2 & 2 & 2 & $\mathrm{X}$ \\
\hline Chrysophyllum marginatum (Hook. \& Arn.) Radlk. & 2 & 2 & 1 & 2 & $\mathrm{X}$ \\
\hline Duguetia lanceolata A. St.-Hil. & 2 & 1 & 2 & 1 & - \\
\hline Qualea dichotoma (Mart.) Warm. & 2 & 1 & 2 & 1 & - \\
\hline Aspidosperma cylindrocarpon Müll. Arg. & 2 & 0 & 2 & 0 & - \\
\hline Aspidosperma discolor A. DC. & 2 & 0 & 2 & 0 & - \\
\hline Genipa americana $\mathrm{L}$. & 2 & 0 & 2 & 0 & $\mathrm{X}$ \\
\hline Heisteria ovata Benth. & 2 & 0 & 2 & 0 & $\mathrm{X}$ \\
\hline Matayba elaeagnoides Radlk. & 2 & 0 & 2 & 0 & - \\
\hline Neea hermaphrodita S. Moore & 2 & 0 & 2 & 0 & - \\
\hline Myracrodruon urundeuva Allemão & 1 & 3 & 1 & 3 & - \\
\hline Rhamnidium elaeocarpum Reissek & 1 & 2 & 1 & 2 & - \\
\hline Terminalia phaeocarpa Eichler & 1 & 2 & 0 & 2 & - \\
\hline Apeiba tibourbou Aubl. & 1 & 1 & 1 & 1 & - \\
\hline Aspidosperma cuspa (Kunth) S.F. Blake ex Pittier & 1 & 1 & 1 & 1 & - \\
\hline Callisthene major Mart. & 1 & 0 & 1 & 0 & - \\
\hline Calophyllum brasiliense Cambess. & 1 & 0 & 1 & 0 & - \\
\hline Calyptranthes lucida Mart. ex DC. & 1 & 0 & 1 & 0 & - \\
\hline Cardiopetalum calophyllum Schltdl. & 1 & 0 & 1 & 0 & - \\
\hline Casearia gossypiosperma Briq. & 1 & 0 & 1 & 0 & - \\
\hline Chomelia pohliana Müll. Arg. & 1 & 0 & 1 & 0 & - \\
\hline Ficus sp2 & 1 & 0 & 1 & 0 & - \\
\hline Guarea guidonia (L.) Sleumer & 1 & 0 & 1 & 0 & $\mathrm{~W}$ \\
\hline Pera glabrata (Schott) Poepp. ex Baill. & 1 & 0 & 1 & 0 & $\mathrm{~W}$ \\
\hline Senna silvestris (Vell.) H.S. Irwin \& Barneby & 1 & 0 & 1 & 0 & - \\
\hline Campomanesia velutina (Cambess.) O. Berg & 0 & 5 & 1 & 3 & - \\
\hline Tabebuia impetiginosa (Mart. ex DC.) Standl. & 0 & 2 & 0 & 2 & - \\
\hline Virola sebifera Aubl. & 0 & 2 & 0 & 2 & - \\
\hline Anadenanthera macrocarpa (Benth.) Brenan & 0 & 1 & 1 & 1 & - \\
\hline Tapirira peckoltiana Engl. & 0 & 2 & 0 & 1 & - \\
\hline Aegiphylla sellowiana Cham. & 0 & 1 & 0 & 1 & $\mathrm{~W}$ \\
\hline Cordia alliodora (Ruiz \& Pav.) & 0 & 1 & 0 & 1 & - \\
\hline Dendropanax cuneatum DC & 0 & 1 & 0 & 1 & - \\
\hline Dilodendron bipinnatum Radlk. LC & 0 & 1 & 0 & 1 & - \\
\hline Leguminosa 1 & 0 & 1 & 0 & 1 & - \\
\hline Luehea grandiflora Mart. Zucc. & 0 & 1 & 0 & 1 & - \\
\hline Simira sampaioana (Stand1.) Steyerm. & 0 & 1 & 0 & 1 & - \\
\hline Tabebuia roseo-alba (Ridl.) Sand. & 0 & 1 & 0 & 1 & - \\
\hline Eugenia involucrata DC. & 0 & 0 & 1 & 0 & - \\
\hline Machaerium villosum Vogel. & 0 & 1 & 0 & 0 & - \\
\hline Rudgea virbunoides (Cham.) Benth. & 0 & 1 & 0 & 0 & - \\
\hline
\end{tabular}




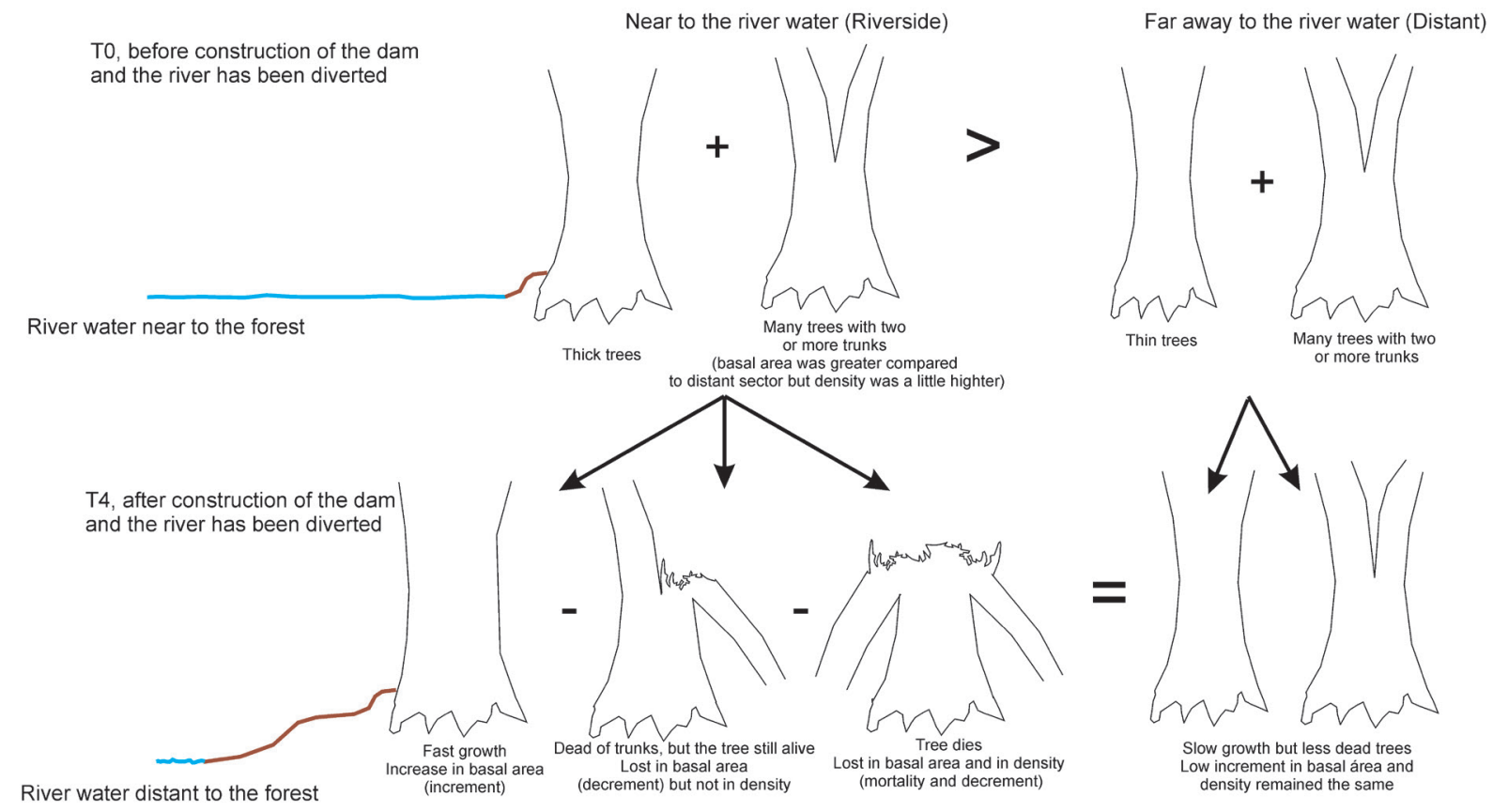

Fig. 3. Major changes that drives the community changes. Before river diversion, the sectors near the river had greater basal areas because they had many thick trees while distant sectors had thin trees (the density was statistically similar). After four years of river diversion, there were many trunks of still alive trees and dead trees in the sector closer to the river. Even with high growth, the basal area in this sector was severely reduced and became similar to the distant sector (which already has small basal area).

$p=0.83, \mathrm{df}>500$, to riverside and $\mathrm{p}=0.70, \mathrm{df}>500$ to inland sector). However, riverside and inland diversity before damming were distinct (Hutcheson " $\mathrm{t}$ " test $\mathrm{p}=0.04$, df $>500$ ), but became similar after damming (Hutcheson " $t$ " test $\mathrm{p}=0.17, \mathrm{df}>500$ ). The similarity of dead trees was $48 \%$ and recruits similarity was $62 \%$. With more similar recruited trees, the floristic similarity in these two sectors raised from 54 to $56 \%$ (Morisita-Horn) and 56 to $60 \%$ (Jaccard).

\section{Dynamic rates in each riparian forest sector}

The dynamic rates were higher in the riverside compared to inland. The riverside had higher mortality than the inland sector ( 6.01 to $4.64 \%$ year $\left.^{-1}\right)$, outgrowth rates (6.11 to $1.91 \%$ year $^{-1}$ ) and ingrowth (5.42 to $3.90 \%$ year $^{-1}$ ). These results reflect the large loss of stems and mortality of thick trees suffered by riverside plots (most of them were moisture dependent species and larger than $20 \mathrm{~cm}$ of diameter at breast height). The same did not occur in the inland sector where most dead trees were thin. Thus individuals ( 4.55 to $4.17 \%$ year $^{-1}$ ) and basal area (5.76 to $2.91 \%^{\%}$ year $^{-1}$ ) turnover rates were higher in the riverside sectors. However the net changes show high loss of individuals per year in the riverside (-5.94 to $-1.93 \%$ year $\left.^{-1}\right)$ and the basal area was reduced only in the riverside with a positive growth in the inland sector (-4.46 to $2.47 \%$ year $^{-1}$ ). Then, in general, only the riverside sectors presented a negative overall net change (-5.20 to $0.27 \%$ year $\left.^{-1}\right)$.

\section{DISCUSSION}

Water flow reduction due to the dam construction decrease soil moisture near the shore (riverside) until $30 \mathrm{~cm}$ depth, mainly in dry months not $15 \mathrm{~m}$ distant to the shore (inland), confirming our first hypothesis. The lack of rains on dry season is strong and distant to the river's direct influence, the soil had already little water available. Then the water flow reduction did not affect soil moisture at $15 \mathrm{~m}$ distance from the river. The dam construction reduced the soil moisture, making riverbank as arid as inland plots in the end of dry season and or in the middle of the rainy season. A study in another riparian forest showed that major root biomass is concentrated until $30 \mathrm{~cm}$ (Kiley \& Schneider 2005), hence many trees whose roots do not surpass this depth may have been affected. Surface and groundwater are important because they strongly influence species composition, community structure and biological diversity (Ehleringer \& Dawson 1992, Fujieda et al. 1997, Munoz-Reinoso 2001, Stromberg et al. 2001). The reduction in soil water availability can negatively affect the photosynthesis and biomass conversion (Breshears \& Barnes 1999) and consequently decreases in riparian forest species performance and survival (Smith et al. 1991).

Despite of non-significant difference in number of trees in four years of monitoring, the basal area was reduced due to mortality and dead trunks of live trees. 
The basal area was statistically higher at the riverside in T0, and even the riverside sector getting more growth, the basal area differences was strongly reduced. Then, the riverside sector is becoming structurally similar to the inland sector. Original riparian forests commonly cover more than $40 \mathrm{~m}^{2}$.ha-1 of basal area (Rodrigues et al. 2010) while dry forests (usually forests distant from water resources whose climatic seasonality has a high influence on the structure and floristic) cover about 27 $34 \mathrm{~m}^{2}$.ha- (Lopes et al. 2012). In four years, the reduction in riverside was $4 \mathrm{~m}^{2} \cdot \mathrm{ha}^{-1}$ (45.63 to $41.59 \mathrm{~m}^{2} \cdot \mathrm{ha}^{-1}$ ) and if it persists, these sectors will structurally become a seasonal dry forest in few years. Seasonal dry forests are common in regions with marked seasonal climate and independent of direct river influence, characterized by tree deciduousness in dry seasons and structurally distinct from riparian forests.

After water flow reduction, in severe dry months, only plots near the river became drier. Probably the river had high influence on soil moisture near the riverside, but now this sector depends on rains even as inland sectors. This may be the main factor for the high mortality of typical understory trees on the riverbank because many water-dependent understory species had small trees and died in four years (Vale et al. 2015b) probably by having shallow root system and have difficulty to reach high depth to access soil water. The death of many understory trees was the major cause of the diversity change, which was distinct between the riverside to the inland before damming became similar after four years.

Different species are dying when we compare riverside and inland sectors, but species recruitment was similar. For example, the Morisita-Horn similarity of dead trees in the riverside and the inland sectors were quite distinct (less than $50 \%$ of similarity), but the recruits were $62 \%$ similar. This shows that these too sectors are slowly becoming more similar to each other, which means changes in the forest flora over the years. This result was more evident for understory species because canopy species usually present deeper roots and this kind of plants are the most able to obtain water in deeper soil layers (Breshears \& Barnes, 1999) even in drought months (Saha et al., 2008).

Underground water use to avoid drought is an Eco physiological traits in seasonal forests (Borchert, 1998), but it is not required in moist environments. Therefore, many moist adapted species in the riverside will probably keep dying and open spaces to be occupied by species better adapted to prolonged drought (Vale et al., 2015b). Many of recruits that are established in the riverbank are composed by dense species in the inland sector, such as Byrsonima laxiflora, Siparuna guianensis and Xylopia aromatic. These are non-water dependent understory species and can occur on forest edges, where water availability is lower than in the forest interior (Laurance et al., 2009). This is another evidence of the high changes occurring in forest structure. Then, our second hypothesis was partially comproved. The riverside and inland sectors changes in different ways after water flow reduction, and the majority of changes occurred in the riverside sector. However, was expected more significant changes in inland sectors too and few notable changes occurred. Then, this sector was little affected by the water flow reduction.

The higher mortality and loss of basal area in the riverside sector partially confirms our third hypothesis, that sectors previously near the riverside have higher negative dynamics rates. Actually the number of recruits was similar; the riverside sectors had higher growth, and the diversity suffer little change in four years of water regulation. Nevertheless, the high mortality is transforming the riverbank in more open areas with smaller density and basal area, such as the inland sector. The mortality and mainly outgrowth rates were superior in the riverside, leading to an intense dynamic in four years of water reduction. While dynamic rates in inland plots is consistent to Brazilian seasonal dry forests (about 3\% year ${ }^{-1}$ : Oliveira et al. 2014) the riverside had rates that surpassed $4.5 \%$ year $^{-1}$ for mortality, outgrowth, ingrowth, individuals turnover and basal area turnover. These values are higher than forest submitted to drastic disturbances as edge effect (OliveiraFilho et al. 1997), El Niño influence (Laurance et al. 2009) and are similar to forests subjected to flooding (Silva et al. 2011). Then, we can consider the reduction in water flow a great impact to riparian forests and this impact can be considered a large-scale disturbance to large hydrographic dammed riparian system. Large-scale disturbances cause drastic negative effects on trees communities and also change forest structure and promote high turnover rates with sudden and dramatic changes in abundance and spatial arrangement of dominant plants (Oliveira et al. 1997, Gitlin et al. 2006).

In general, the riverside sector become as drier as the inland sector and this water moisture reduction may change the soil microclimate and consequently on plant establishment. Floristic gradients in forest are related with soil, slope, topography, and water availability (Gartlan et al. 1986, Oliveira-Filho et al. 1998, Oliveira-Filho et al. 1994, Berg \& Oliveira-Filho 1999), due to the diversity of microclimates generated enhance the diversity and productivity (Naiman \& Decamps 1997). In this riparian forest, only water available was modified and severely reduced. Before flow regulation, it was expected that the river provided high soil moisture in many riparian forest sectors. Occasional floods, for example, can create distinct regeneration niches that facilitate species coexistence (Naiman \& Decamps 1997) and this kind of event became null. Therefore, water absence transformed moist sectors making them similar to those outlying areas to the river. The short term consequences were mortality of water dependent trees (see the species list on Table 4), especially from understory were not compensated by recruitment of more drought tolerant trees. We predict, as a long term consequence, that the riverside sector will reduce its own density and total basal area becoming more similar to a semidecidual seasonal forest. 
Considering that early life stages and herbs are likely to be particularly sensitive and vulnerable to extreme water deficit conditions (Leuzinger et al. 2005, Stefan et al. 2007), negative impacts may occur in other component of flora, mainly to water dependent sectors. Some indications of this tendency could be made by high recruitment and mortality of understory species (those with fast dynamic in the community), in riverside plots. Furthermore, the understory species recruited in riverside plots were common to the distant sectors, and the riverbed became floristically more similar to distant sectors.

The riparian sectors nearest the river will probably be replaced, over the years, by less water dependent species. Hence, the riparian moist forest will become another physiognomy, less water dependent in dry season, trees and basal area (probably a seasonal dry forest, a kind of forest common in regions with marked seasonal climate and independent of direct river influence). Our work focus in tree community and probably the most stable portion of entire vegetation, however in only four years of reduced water flow, the tree community was severely modified and this implies in more changes during the next years.

\section{ACKNOWLEDGEMENTS}

The authors thank Coordenação de Aperfeiçoamento de Pessoal de Nível Superior (Process 2498/09-0), Programa de Apoio aos Cursos Cinco, Seis e Sete, Fundação de Amparo à Pesquisa do Estado de Minas Gerais (Process CRA-30058-12) for financial support, and Programa de Concessão de Bolsa de Incentivo ao Pesquisador da Universidade Estadual de Goiás.

\section{REFERENCES}

Alvares, C.A., Stape, J.L., Sentelhas, P.C., Gonçalves, J.L.M. \& Sparovek, P.C. 2013. Koppen's climate classification map for Brazil. Meteorologische Zeitschrift 22(6): 711-728.

Berg, E.V.D. \& Oliveira-Filho, A.T. 1999. Spatial partitioning among tree species within an area of tropical montane gallery forest in south-eastern Brazil. Flora 194: 249-266.

Borchert, R. 1998. Responses of tropical trees to rainfall seasonality and its long-term changes. Climatic Change 39: 381-393.

Breshears, D.D. \& Barnes, F.J. 1999. Interrelationships between plant functional types and soil moisture heterogeneity for semiarid landscapes within the grassland/forest continuum: a unified conceptual model. Landscape Ecology 14: 465-478.

Consórcio Capim Branco e Energia - CCBE. 2005. Informativo Mensal do Consórcio Capim Branco e Energia. 5p. <http://www.ccbe.com. $\mathrm{br} /$ comunicacao/informativos/set_05.pdf $>$.

Ehleringer, J.R. \& Dawson, T.E. 1992. Water-uptake by plants perspectives from stable isotope composition. Plant Cell and Environment 15: 1073-1082.

Empresa Brasileira de Pesquisa Agropecuária (EMBRAPA Solos) 2006. Sistema brasileiro de classificação de solos $2^{\circ}$ ed. Rio de Janeiro. $306 \mathrm{p}$.

Fearnside, P.M. 2002. Greenhouse gas emissions from a hydroelectric reservoir (Brazil's Tucurui Dam) and the energy policy implications. Water Air and Soil Pollution 133: 69-96.

Friedl, G. \& Wuest, A. 2002. Disrupting biogeochemical cycles Consequences of damming. Aquatic Sciences 64: 55-65.

Friedman, M. 1939. The use of ranks to avoid the assumption of normality implicit in the analysis of variance. Journal of the American Statistical Association 32 (200): 675-701.
Fujieda, M., Kudoh, T., deCicco, V. \& deCalvarcho, JL. 1997. Hydrological processes at two subtropical forest catchments: The Serra do Mar, Sao Paulo, Brazil. Journal of Hydrology 196: 26-46.

Gartlan, J.S., Newbery, D.M., Thomas, D.W. \& Waterman, P.G. 1986. The influence of topography and soil-phosphorus on the vegetation ok Korup Forest Reserve, Cameroun. Vegetatio 65: 131-148.

Gitlin, A.R., Sthultz, C.M., Bowker, M.A., Stumpf, S., Paxton, K.L., Kennedy, K., Munoz, A., Bailey, J.K. \& Whitham T.G. 2006. Mortality gradients within and among dominant plant populations as barometers of ecosystem change during extreme drought. Conservation Biology 20: $1477-1486$.

Kiley, D.K. \& Schneider, R.L. 2005. Riparian roots through time, space and disturbance. Plant and Soil 269: 259-272.

Korning, J. \& Balslev, H. 1994. Growth-rates and mortality patterns of tropical lowland tree species and the relating to forest structure in amazonian Ecuador. Journal of Tropical Ecology 10: 151-166.

Laurance, S.G.W., Laurance, W.F., Nascimento, H.E.M., Andrade, A., Fearnside, P. M., Rebello, E.R.G., \& Condit, R. 2009. Long-term variation in Amazon forest dynamics. Journal of Vegetation Science 20: $323-333$.

Leuzinger, S., Zotz, G., Asshoff, R. \& Korner, C. 2005. Responses of deciduous forest trees to severe drought in Central Europe. Tree Physiology 25: 641-650.

Lilliefors, H. W. 1967. On the Kolmogorov-Smirnov test for normality with mean and variance unknown, Journal of the American Statistical Association: 62(318), 399-402.

Lopes, S.F., Schiavini, I., Oliveira, A.P. \& Vale, V.S. 2012. An Ecological Comparison of Floristic Composition in Seasonal Semideciduous Forest in Southeast Brazil: Implications for Conservation. International Journal of Forestry Research, 2012: 1-14.

Loreau, M., Naeem, S., Inchausti, P., Bengtsson, J., Grime, J.P., Hector, A., Hooper, D.U., Huston, M.A., Raffaelli, D., Schmid, B., Tilman, D. \& Wardle D.A. 2001 Ecology - Biodiversity and ecosystem functioning: Current knowledge and future challenges. Science 294: 804-808.

Munoz-Reinoso, J.C. 2001. Vegetation changes and groundwater abstraction in SW Donana, Spain. Journal of Hydrology 242: 197-209.

Naiman, R.J. \& Decamps, H. 1997. The ecology of interfaces: Riparian zones. Annual Review of Ecology and Systematics 28: 621-658.

Naiman, R.J., Decamps, H. \& Pollock, M. 1993. The role of riparian corridors in maintaining regional biodiversity. Ecological Applications 3: 209-212.

Nilsson, C. \& Berggren, K. 2000. Alterations of riparian ecosystems caused by river regulation. Bioscience 50: 783-792.

Nilsson, C. \& Grelsson, G. 1995. The fragility of ecosystems: A review. Journal of Applied Ecology 32: 677-692.

Nilsson, C. \& Svedmark, M. 2002. Basic principles and ecological consequences of changing water regimes: Riparian plant communities. Environmental Management 30: 468-480.

Nilsson, C., Jansson, R. \& Zinko, U. 1997. Long-term responses of rivermargin vegetation to water-level regulation. Science 276: 798-800.

Oliveira-Filho, A.T., Carvalho, W.A.C., Machado, E.L.M., et al. 2007. Dinâmica da comunidade e populações arbóreas da borda e interior de um remanescente florestal na Serra da Mantiqueira, Minas Gerais, em um intervalo de cinco anos (1999-2004). Revista Brasileira de Botânica 30: 149 - 161.

Oliveira-Filho, A.T., Curi, N., Vilela, E.A. \& Carvalho, D.A. 1998. Effects of canopy gaps, topography, and soils on the distribution of woody species in a central Brazilian deciduous dry forest. Biotropica 30: 362-375.

Oliveira-Filho, A.T., Vilela, E.A., Gavilanes, M.L. \& Carvalho, D.A. 1994. Comparison of the woody flora and soils of six areas of the montane semideciduous forest in southern Minas Gerais, Brazil. Edinburgh Journal of Botany 51: 355 - 389.

Oliveira, A.T., Mello, J.M. \& Scolforo, J.R.S. 1997. Effects of past disturbance and edges on tree community structure and dynamics within a fragment of tropical semideciduous forest in south-eastern Brazil over a five-year period (1987-1992). Plant Ecology 131(1):45-66.

Oliveira, A.P., Schiavini, I., Vale, V.S., Lopes, S.F., Arantes, C.S., Gusson, A.E., Prado Júnior, J.A., Dias-Neto, O.C. 2014. Mortality, recruitment and growth of the tree communities in three forest formations at the Panga Ecological Station over ten years (1997-2007). Acta Botanica Brasilica 28(2): 234-248. 
Ravenga, C., Brunner, J., Henninger, N., Kassen, K. \& Payne, R. 2000. Freshwater systems, pilot analysis of global ecossystems. World Resources Institute, Washington. 78p.

Rocha, C.T.V, Carvalho, D.A., Fontes, M.A.L., Oliveira-Filho, A.T., Berg, E.V.D. \& Marques, J.J.G.S.M. 2005. Comunidade árbores de um continuum entre floresta paludosa e de encosta em Coqueiral, Minas Gerais, Brasil. Revista Brasileira de Botânica 28: 203 - 218.

Rodrigues, S.C. \& Silva, .I. 2012. Dam construction and loss of geodiversity in the Araguari River Basin, Brazil. Land degradation \& development. 23: 419 - 426.

Rodrigues, V.H.P., Lopes, S.F., Araújo, G.M. \& Schiavini, I. 2010. Composição, estrutura e aspéctos ecológicos da floresta ciliar do rio Araguari no Triângulo Mineiro. Hoehnea 37: 87 - 105.

Saha, S., Strazisar, T.M., Menges, E.S., Ellsworth, P. \& Sternberg, L. 2008. Linking the patterns in soil moisture to leaf water potential, stomatal conductance, growth, and mortality of dominant shrubs in the Florida scrub ecosystem. Plant and Soil 313: 113-127.

Schume, H., Grabner, M. \& Eckmullner, O. 2004. The influence of an altered groundwater regime on vessel properties of hybrid poplar. Trees-Structure and Function 18: 184-194.

Sheil, D., Burslem, D. \& Alder, D. 1995. The interpretation and misinterpretation of mortality-rate reasures. Journal of Ecology 83: 331-333.

Sheil, D., Jennings, S. \& Savill, P. 2000. Long-term permanent plot observations of vegetation dynamics in Budongo, a Ugandan rain forest. Journal of Tropical Ecology 16: 765-800.

Shepherd, G.J. 2004. Fitopac-Shell 1.6.4. Universidade Estadual de Campinas, Campinas. 76p.

Smith, S.D., Wellington, A.B., Nachlinger, J.L. \& Fox, C.A. 1991. Functional-responses of riparian vegetation to streamflow diversion in the eastern Sierra-Nevada. Ecological Applications 1: 89-97.
Silva, K.E., Souza, C.R., Azevedo, C.P. \& Rossi, L.M.B. 2011 Forest dynamic, carbon stock and phytosociology of terra firme dense forest in Central Amazonia. Scientia Forestalis 43(105):193-201.

StatSoft I. 2005. Programa computacional -data analysis software system 7.1 (Statistica). CD ROM.

Stefan, J., McDonald, A.J., Johnson, M.S., Feldpaush, T.R., Couto, E.G. \& Riha, S.J. 2007. Relationships between soil hydrology and forest structure and composition in the southern Brazilian Amazon. Journal of Vegetation Science 18: 183 - 194.

Stromberg, J.C. 2001. Restoration of riparian vegetation in the southwestern United States: importance of flow regimes and fluvial dynamism. Journal of Arid Environments 49: 17 - 34.

Truffer, B., Bratrich, C., Markard, J., Peter, A., Wuest, A. \& Wehrli, B. 2003. Green Hydropower: The contribution of aquatic science research to the promotion of sustainable electricity. Aquatic Sciences 65: 99-110.

Vale, V.S., Araújo, G.M., Schiavini, I., Prado-Júnior, J.A., Gusson, A.E. 2014 Dams consequences to the woody regeneration layer of dry forests. Natureza on line 12(1): 19-27.

Vale, V.S., Schiavini, I., Araújo, G.M., Gusson, A.E., Lopes, S.F., Oliveira, A.P., Prado-Júnior, J.A., Arantes, C.S. \& Dias-Neto, O.C. 2013. Fast changes in seasonal forest communities due to soil moisture increase after damming. International. Journal of Tropical Biology 61(4): 1901-117.

2015b. Effects of reduced water flow in a riparian forest community: aconservation approach. Journal of Tropical Forest Science 27(1): 13-24.

Vale, V.S., Schiavini, I., Prado-Júnior, J.A., Oliveira, A.P., Gusson, A.E. 2015a. Revista Chilena de Historia Natural 88(13):1-11.

Ward, J.V. 1998. Riverine landscapes: Biodiversity patterns, disturbance regimes, and aquatic conservation. Biological Conservation 83(3): 269-278. 